\title{
Egypt's Economic Transition: Challenges and Prospects
}

\author{
Robert Springborg
}

\begin{abstract}
Egypt faces the Herculean task of simultaneously rebuilding its polity and economy and doing so in the absence of broad social consensus on either. State institutions underpinning both, ranging from the legislative and judicial branches to executive agencies with direct responsibility for economic management require substantial if not total overhauls. It is only the bedrock of the deep state that remains firmly in place, but that solid foundation is an inappropriate one upon which to construct a competitive and inclusive political economy. Any regime, in short, would face profound challenges in either creating a 'second republic' or re-invigorating the first, now badly discredited one. The military regime that seized power in July 2013, faces particularly intense ones not only because of the means by which it assumed power, but also because of its very nature. Military regimes are out of step with the times. One of the reasons they are is that they fail to deliver development, thereby suggesting that militaries are inherently incapable of devising and implementing successful economic models. Whether the Egyptian one might differ in this regard is the question this paper addresses. It does so by providing a brief overview of the broad political and economic challenges Egypt faces, followed by more detailed investigations of specific challenges in the areas of fiscal management, fostering a capable business elite, improving the capabilities and performance of the labor force, and generating growth in particular sectors. An effort is then made to foretell the 'Sisinomic' model likely to be crafted to meet these and other challenges, followed by an evaluation of its prospects for success.
\end{abstract}

\section{Introduction}

Egypt faces the Herculean task of simultaneously rebuilding its polity and economy and doing so in the absence of a broad social consensus on either. Moreover, the status quo ante has been discredited, as the 'January 25 Revolution' attested, so its economic and political models provide only limited foundations, at best, for erecting new ones. State institutions underpinning both, ranging from the legislative and judicial branches to executive agencies with

(C) ROBERT SPRINGBORG, 2017 | DOI 10.1163/9789004336452_011

This is an open access chapter distributed under the terms of the CC-BY-NC License. Springborg - 9789004336452 
direct responsibility for economic management, including taxation and regulatory bodies, were not particularly robust prior to January 2011. They have been so buffeted by events since then that in most cases they require substantial if not total overhauls, as the new constitution of 2014 signifies. Only the bedrock of the deep state remains firmly in place, but that solid foundation is an inappropriate one upon which to construct a competitive and inclusive political economy.

Any regime, in short, would face profound challenges in either creating a 'second republic' or re-invigorating the first, now badly discredited. The military regime that seized power in July 2013 faces particularly intense trials not only because of the means by which it assumed power-which has created a backlash of violent and non-violent dimensions, both of which challenge its legitimacy - but also because of its very nature. Military regimes are out of step with the times. One of the reasons for this is that, whether in Latin America, Africa or Asia, they have failed to deliver development, thereby suggesting that militaries may be inherently incapable of devising and implementing successful economic models. Whether or not the Egyptian military might be the exception to this rule is the question this chapter addresses. It will do so by providing a brief overview of the broad political and economic challenges Egypt faces, followed by more detailed investigations of specific challenges in the areas of fiscal management, fostering a capable business elite, improving the capabilities and performance of the labour force and generating growth in particular sectors. An effort will then be made to predict the 'Sisinomic' model likely to be crafted to meet these and other challenges; and this will be followed by an evaluation of its prospects for success.

\section{$2 \quad$ President Al-Sisi's Impoverished Inheritance}

President al-Sisi has inherited a state, a market, and relations between them that are sorely in need of overhaul. On comparative scales of state performance in managing the economy - whether the World Bank's Governance or Ease of Doing Business indices, Transparency International's Corruption Perception Index, the Bertelsmann Foundation's Transformation Index, The Economist Intelligence Unit's Business Environment Ranking or the Arab Reform Initiative's Democracy Index, the last of which contains several dimensions of state economic management-Egypt significantly underperforms regional and global comparators. ${ }^{1}$ The much noted, brief, dramatic improvement on the Ease of

1 On the Arab Reform Initiative's Democracy Index, see Shikaki et al. (2011). For a review and assessment of Egypt's performance on various governance indices, see Springborg (2013). The 
Doing Business Index in 2007-08 resulted from strategic legislative changes that were intended precisely to improve Egypt's ranking on that index but were never implemented (Springborg, 2013). Indeed, the gap between official policy and actual performance in state economic management is, according to the Arab Reform Initiative's Democracy Index, greater in Egypt than in any other Arab country included in the assessment (Shikaki et al., 2011, 28). That overcoming the legacy of poor state management of the economy will not be quick or easy is suggested by the World Bank's 2015 annual Doing Business report, published some fifteen months after General al-Sisi seized power. Egypt's ranking remained essentially unchanged over that period, ranking 112th out of 189 countries. Its lowest performance, 152nd place, was on the key indicator of 'enforcing contracts', reflecting — at best—stagnation of the vital legal/judicial system and an overall weakness of the rule of law. ${ }^{2}$

Mubarak's increasingly decrepit, corrupt state relied ever more heavily on rents as the years passed, particularly on those from the hydrocarbon sector, which by the global collapse of 2008 had come to provide about half of the country's total exports (Springborg, 2012). The surge of foreign direct investment (FDI), which peaked at USD 11.5 billion in 2007 , was roughly equally divided between investment in the hydrocarbon sector, almost all of which was from multinational oil and gas companies, and investment related to real estatewhether in commercial or residential building or tourism - almost all of which was from Gulf Cooperation Council (GCC) states. While strictly speaking FDI is not rent, its concentration in the main rent generating sectors reflects the state's dependence upon and interest in those rents and its concomitant disinterest in steering and stimulating broader economic growth. ${ }^{3}$ Cronyism — the

Economist Intelligence Unit's Business Environment Ranking of 2014 ranked Egypt 69th out of 82 countries, a deterioration of eight places since the 'January 25, 2011 Revolution', at which time Egypt was already in the bottom half of the 17 Middle Eastern and African countries ranked. Egypt's performance on this index, which is composed of ten separate criteria including taxes, policy with regards to free enterprise and competition, and foreign trade and exchange controls as well as measures less directly related to government, is better than on the other indexes; probably because Egypt's size creates substantial market opportunities. For a review of Egypt's scoring, see http://country.eiu.com/article.aspx?articleid=300997214 $\&$ Country=Egypt\&topic $=$ Business\&subtopic $=$ Business + environment\&subsubtopic $=$ Rankin gs+overview.

2 For an analysis of the World Bank's 2015 Doing Business report, see Abaza (2014b).

3 That Arab FDI is more likely to be rent seeking than FDI from sources external to the region is further supported by evidence with regards to the motivations of Arab investors. According to Khalid Sekkat, 'human capital, quality of institutions, infrastructure and openness don't affect an Arab investor's decision to locate in a given Arab country while they affect non-Arab investors'. (Sekkat, 2014). FDI fell dramatically as a result of the January 25 Revolution, dropping to a net outflow of half a billion dollars in 2011 before recovering to some USD 2.8 billion 
market's conjoined twin to a corrupt, rent seeking state-grew in tandem with these maladies of governance, as recent research has empirically demonstrated. Amirah El-Haddad's careful study of vertical integration in Egypt's clothing industry, for example, found that 'Those [businessmen] linked to power, prospered, whilst the businesses of others foundered against the wall of bureaucracy and red tape'. (El-Haddad, 2013, 1). Hamouda Chekir and Ishac Diwan's investigation of share prices on the Cairo exchange revealed that 'Connected firms have lost more value than others during these events [i.e. the 25 January Revolution] on account of their connections'. (Chekir and Diwan, 2013, 13). Egypt's Lost Power, a documentary on Egypt's gas industry prepared by al Jazeera, alleges that the country lost billions of dollars of potential revenue as a result of profits extracted from commercial transactions, most notably with Israel, by Mubarak's cronies, particularly those drawn from the military and intelligence services. ${ }^{4}$

With state-market relations driven by rent seeking, the performance of economic sectors varied according to their proximity to those rents. Tourism, for example, prospered in part because it is primarily a land-based activity. Land transactions provided substantial rents, particularly to the military, the largest single owner of land in Egypt. ${ }^{5}$ The telecom industry flourished behind barriers to new entrants to the mobile phone market. Manufacturing industry, however, stagnated unless servicing protected local markets. As a consequence of this distorted growth the labour market became misshapen, with unemployment and education increasingly positively correlated and the already low female participation rate steadily dropping as informal steadily supplanted formal employment, accounting for more than two thirds of new jobs by the end of the Mubarak era. Although the rate of growth of the civil service slowed, it accounted for some seven million jobs by the time of the 'revolution', accounting for more than half of all female employment and 30 per cent of total employment. A 2005 survey revealed that the single most important source of family income even in rural areas was government employment, with agriculture coming second (Mayfield, 2012, 293-297).

in 2012. In the first quarter of 2015 it was almost double that of the previous quarter, rising to some USD 4.8 billion. This appears to have been the result of announcements made at the March donors' conference rather than the commencement of a sustained, dramatic rise in FDI. See the Egypt Foreign Direct Investment website at http://www.tradingeconomics.com/ egypt/foreign-direct-investment.

This documentary can be viewed at http://www.aljazeera.com/investigations/.

5 This was already the case in Mubarak's Egypt. Under President al-Sisi the military has deepened and broadened its control of land throughout the country. For a description of the ways and means by which this has been accomplished, and for estimates of the amount of land the military has recently appropriated, see Abul-Magd (2016, forthcoming). 
With little demand for highly qualified graduates, secondary and tertiary education continued to deteriorate, with even newly created private universities producing graduates as underqualified as those graduating from the old, decaying public ones (Assaad, Badawy, and Krafft, 2014). Although the birth rate declined during the first decade of the Mubarak era, it began to grow again after that as a result of female members of the 'youth bulge' reaching child bearing age and a surprising increase in fertility rates driven by increasing poverty and decreasing female participation in the labour force (Krafft and Assaad, 2014). In 2013, 2.6 million babies were born, almost 50 per cent more than a decade previously. By 2011 almost 800,000 new jobs were required annually to stabilise the unemployment rate, whereas only some half a million annually had been needed when Mubarak took power in 1981. The rate of economic growth required to produce this number of jobs, in excess of 7 per cent, was only almost achieved during one year of the Mubarak era. As the private sector failed to expand sufficiently rapidly to absorb new entrants to the labour market, the state continued to act as a labour sponge. In a related effort to deter unrest, the government spent steadily more of its budget on consumer subsidies, most notably for energy, while not increasing tax revenues sufficiently to absorb those costs, which consumed over one fifth of all government expenditures by the end of the Mubarak era. The resultant annual budget deficit bounced along at some 7-8 per cent for Mubarak's final years, thereby adding to the accumulated public debt, interest payments on which also absorbed more than one fifth of the budget. Savings and investment declined in parallel, dropping to some 12 per cent of Gross Domestic Product (GDP) by 2010, placing Egypt in the world's lowest quartile of countries on this vital measure of economic growth (World Bank, 2016).

These interconnected problems of the civilian economy, resulting from a rent seeking state nurturing its favoured clients, were exacerbated by the military's increasing interventions in that economy. Military- and officer-owned companies benefiting from a host of subsidies and preferential treatmentsof which conscript labour, tax-free status and preferential treatment in government contracting were key - to say nothing of immunity from official oversight and regulation, increasingly shouldered aside civilian competitors. ${ }^{6}$ Competition over rents between officers and cronies intensified, becoming a major cause of the military refusing to stand by Mubarak. The military was particularly sensitive to any efforts to encroach on its economic autonomy and the tax-exempt status of its enterprises. The two civilian cabinet members

6 For illustrative examples, see Abul-Magd (2016, forthcoming). 
who were brave enough to advocate a change to the latter arrangementMinister of Finance Yusuf Butrus Ghali and Minister of Trade and Investment Rashid Muhammad Rashid - were the only high profile ministers not related to the Mubaraks subsequently tried, convicted and then pursued abroad by the military-dominated government. ${ }^{7}$ In sum then, President al-Sisi inherited a misshapen political economy distorted by rent seeking and the overweening role of his very own military. The challenges-resulting from this state of affairs - that he now faces include managing a deep fiscal crisis, empowering a new business elite, creating jobs and a labour force able to fill them and stimulating growth in various sectors.

\section{Fiscal Problems and Solutions}

Coterminous with Field Marshal al-Sisi's election as president was the announcement by Russell's Annual Index that after a three year review it was downgrading Egypt's status from emerging to 'frontier' market, a term coined in 1992 by the International Finance Corporation to refer to equity markets riskier and less developed than emerging ones (Zaazaa, 2014b). Among the reasons cited by Russell's were currency controls imposed by the central bank-a step taken to slow the rate of devaluation and preserve scarce foreign currency reserves, which at some USD $15^{-17}$ billion were not enough to cover more than three months of imports. But saving the Egyptian pound by restricting access to foreign exchange resulted in collateral damage to the market, to confidence, and to business in general; damage that intensified in 2015 in tandem with the central bank's further tightening as foreign reserves slipped further. For example, Egypt's largest steel producer, Ezz Steel, reported its first-quarter net loss had increased to USD 19.5 million from USD 2.7 million (EGP 136 million from EGP 19 million) in the same period in 2014. The company's chairman attributed the downturn to Ezz's inability to 'source sufficient foreign currency, due to a major change in the regulations of the banking sector'. He noted that, 'as a consequence we had to limit imports of raw materials and to reduce the volume of our production and sales'. (Ahram Online, 2015b). Russell's reclassification followed a series of downgrades, since 2011, of Egypt's sovereign debt by Moody's and Standard and Poor's, taking it to junk bond status. Unable to float an international bond issue for more than a year because of anticipated

7 As reported to the author by eyewitnesses, in cabinet meetings on this issue both men clashed with Minister of Defense Muhammad Husayn Tantawi. 
negative market reactions, Egypt-by the summer of 2014-was facing a severe fiscal crisis. Its sovereign debt, attracting interest of up to 17 per cent, was predicted by the Minister of Finance to require a full quarter of the country's budget to service in the coming financial year, up from 22 per cent in 2013-14. The stimulus package financed by Saudi Arabia and the UAE launched a year previously in the wake of the military's takeover had consumed several billion dollars, but not resulted in more rapid economic growth. Indeed, GDP growth, estimated in early 2013 to be 3 to 3.5 per cent, dropped in the first half of 2014 to 1.2 per cent, its lowest level since the war years of the Nasser and Sadat eras. Inflation reached more than 9 per cent in April 2014, while the currency, despite central bank efforts to prop it up, had fallen 15 per cent against the dollar and euro over the previous twelve months. National savings collapsed in 2013-14 to some 7 per cent, from over 13 per cent the previous year. Unemployment, climbing steadily — according to official figures, which systematically and substantially understate it - from 8.9 per cent in 2010, reached almost 14 per cent in the first quarter of 2014. All that seemed to stand between Egypt and the fiscal calamity of runaway inflation coupled with a collapsing currency and economic stagnation were cash infusions from the Gulf. Small wonder that the Saudi and Emirati governments were both seeking to draw the International Monetary Fund (IMF) into the Egyptian rescue effort, lest they have to pay for it all themselves, with the estimated bill being in the tens of billions of dollars. Left with virtually no alternative, the new al-Sisi government moved in the summer of 2014 to reduce the government deficit by lowering subsidies and increasing taxes, moves which caused Moody's to upgrade its assessment of Egypt's outlook from negative to stable, although not to raise its low (Caa1) government bond rating.

The outlines of the stabilisation plan had long been clear. By 2015, over three-quarters of the annual budget was consumed by a combination of subsidies (27 per cent), government wages (25 per cent) and interest payments (28 per cent), with repayment of loan capital requiring a further 15 per cent. This leaves only some 5 per cent of the budget for all other expenditures, capital and recurring. If the savings and investment rate is to be driven from its present 7 per cent of GDP to the Organisation for Economic Co-operation and Development (OECD) average of around 20 per cent—with any thoughts of reaching Chinese and East Asian figures of over 40 per cent being consigned to the realm of dreams - then subsidies, wages and interest payments have to be dramatically reduced. Of these three, only subsidies and interest payments can be reduced absolutely, assuming that government workers cannot be dismissed, which would be a revolutionary step in Egypt in both the meanings of 
the word. ${ }^{8}$ So, the immediate tasks at hand were to cut subsidies and reschedule loans while hopefully obtaining further debt forgiveness.

Of the two, attacking the debt burden is easier because it involves foreign support, some of which will be forthcoming. But generous as foreigners might prove to be, because Egypt's foreign debt, now approaching USD $5^{\circ}$ billion, is only about 20 per cent of its GDP, whereas its domestic debt is more than 90 per cent of GDP, and because less than 20 per cent of the foreign debt is short term, even substantial relief of the foreign debt would not be a miracle cure. The government's domestic debt is owed overwhelmingly to public and private sector banks. Attracted by the secure, high spreads between interest for deposits and that paid on government paper, and smarting from large portfolios of nonperforming loans they had unwisely extended to Mubarak cronies, these banks have for several years now essentially turned their backs on private borrowers. World Bank and other surveys reveal that the single largest obstacle faced by most Egyptian entrepreneurs is obtaining finance. In this sense, Egypt's banks are zombies, netting profits by collecting deposits on behalf of the government, but contributing almost nothing to the private sector's financial needs.

The government has the usual leverage a debtor has over a creditor and it could be tempted to use it. But since the public sector banks still account directly for about half the loans and deposits of the entire banking sector, and indirectly — as a result of cross ownership — for considerably more, the government would be taking money out of one of its pockets to put it in another, in the process rendering much of the banking sector even more irrelevant to the country's private economy. But given the magnitude of debt servicing this may be the path that is chosen, with concomitant, negative consequences for economic growth as neither the government nor the private sector would retain much access to credit. To the extent Sisinomics depends upon private sectorled growth, the benefits of achieving better fiscal balance at the expense of domestic creditors would come at a substantial cost. Assuming the government

8 As the fiscal imbalance continued to worsen, the government decreed a new civil service law in March, 2015, intended primarily to contain that sector's wage bill, which had risen to 25.2 per cent of the 2015/16 budget's expenditures from 23.9 per cent three years previously. Civil servants' fears that this decree would seriously erode their total remuneration packages, of which the greatest share for many is in the form of 'bonuses' rather than base salaries, led to a series of strikes in the summer of 2015, the most intense of which were staged by tax collectors. In response, President al-Sisi announced on 17 August that the intent of the law was to restructure the civil service, not to reduce salaries, thereby reflecting his fear that labour unrest would spread (Ali and Ahmed, 2015). 
does not want to shoot itself in the foot in this way, the progress it can make on debt reduction can only be gradual, even with foreign support.

Subsidies are another matter. They are a better test of the government's political self-confidence and coherence because, unlike debt renegotiations, which do not directly and visibly impact the public or private sectors of the economy, subsidy reduction would. It thus becomes a question of which constituencies will suffer more. Because food subsidies benefit the poor proportionately more than energy subsidies, and because poverty has steadily increased since 2011, now affecting almost half the population, food subsidies can be better targeted but not substantially reduced; or at least not without a potential popular explosion that no government would want to face. Indeed, in 2014 the government moved to slightly increase the price of bread and to expand the use of smart cards for purchases of subsidised food commodities, but since food subsidies other than bread comprise a small fraction of total subsidies, their more precise targeting had relatively little overall budgetary impact.

This left cutting energy subsidies as the only major, immediate, potential source of government savings. Indeed this, more than any other economic issue divides not only the beneficiaries, but also members of the cabinet and the broader decision-making elite who represent them. Cheap electricity and gas disproportionately benefit the heaviest users, who are the wealthiest 10 per cent of the population. Within that group, owners of energy-intensive companies in the cement, steel, ceramic, fertiliser, petrochemical and related industries benefit most. While electricity prices have risen only slightly in the past decade, the price of natural gas delivered to factory gates was raised in 2014 to some USD 8 per million British thermal units (BTU), compared to a global average of USD 10; the proportionate price differential having dropped substantially since the gas-fired boom of the late Mubarak years when Egyptian industries were paying only some USD 2 per million BTU. It was indeed this cheap energy that resulted in foreign takeovers in several of these industries, most notably cement, about four-fifths of the production of which is now carried out by foreign-owned companies. ${ }^{9}$ That fact alone, combined with the global decline in oil and gas prices from June 2014, makes it easier for the government to raise prices, as indeed it did for some grades of transport fuels in 2014. But even if there is less political resistance to price hikes now, the cabinet remains divided between advocates and opponents of electricity and gas price increases. The ministers of Finance and National Planning, for example, strongly favour price increases, whereas those representing industry and charged with attracting

9 In October 2014, Suez Cement—one of the country's largest producers-reported a 14 per cent decline in net profits for the first nine months of the year, blaming fuel shortages and the new, higher price of USD 8 per million BTU for the decline (Abaza, 2014a). 
foreign investment, led by the ministers of Trade and Investment, want to hold the line against significant price rises (Zaazaa, 2014a ). This choice not only implies relative rewards and costs for different Egyptian constituencies, but future industrial policy and whether it will continue to rely on cheap energy inputs or seek to shift to a broader base, in which the benefits to manufacturing of cheap labour would be key. Precisely because decisions on energy subsidies are of such political and economic significance they require coherent, confident governmental leadership, which has been lacking since the January 25 Revolution. Whether the new government formed under President al-Sisi can provide it in this key area will thus be a crucial test of its preferences, its base, and its coherence. As of early 2015 its potential reform of energy subsidies had primarily targeted transport fuels and electricity and gas for domestic consumption, leaving open the issue of long-term energy prices and potential new sources of supply, both vital for industry. In the last quarter of 2014 the government granted permission to two private sector consortia - one of which brings together Egypt's richest man, Nassif Sawiris, and his company Orascom Construction, and the Abu Dhabi Government's International Petroleum Investment Corporationto construct two coal-fired power plants, one in South Sinai and the other on the Red Sea coast; their very location suggesting that the electricity generated would be used primarily by the cement industry. ${ }^{10}$

On the revenue side of the fiscal imbalance there is also substantial need for reforms that require political will. As on the expenditure side, therefore, they serve as a test of leadership. Privatisation of public sector enterprises would provide little in the way of windfalls as the jewels from that crown were plucked during the Mubarak era. Privatisation would, however, staunch the flow of public monies into them, which remains sizeable even though it has tapered off over the past three years. Clearing these public sector companies' bad debts from the books of their sister public sector banks is in any case a necessary step on the road to restoring effective financial intermediation. Worker remittances remain a substantial source of foreign exchange, if not directly of government revenue. But after rising steadily from 2010 on to reach some USD 19 billion in 2012, they fell significantly in the second half of 2013 as around 300,00o Egyptians were forced to leave Saudi Arabia as a result of its crackdown on foreign labour, while others still fled the growing conflict in Libya. Saudi Arabia alone accounts for about one half of all remittances to Egypt and if it and other GCC states step up expulsions of foreign workers, as they pledge to do, the flow of remittances to Egypt could yet be more negatively affected. Suez Canal revenues have remained relatively flat at USD $5^{-6}$ billion and are projected to increase

10 For further information on, and analysis of, Egypt's energy policy under the military government, see Springborg (2016, forthcoming). 
by less than 5 per cent annually despite the USD 8.5 billion spent on the canal's upgrade, completed by the military in August, 2015. Egypt is now a net importer of fuels, and so does not profit on balance from the export of oil and gas.

Meaningful revenue increases, in sum, will not come from windfalls or from the traditional sources of government revenue. They will have to come from increased taxation. Therein lies the problem, as no one-of course-wants to bear that burden. Indeed, Egyptians have been steadily shirking it since the late 1980 os when tax revenue constituted about 30 per cent of GDP, falling to 20 per cent in 2000 and now to about 15 per cent, well below the average for comparator countries. During the Mubarak era finance minister Yusuf Butrus Ghali, a strong advocate of tax reform, pushed through a new VAT tax and additional sales and real estate taxes. They were, however, never fully implemented, although the legislation and enabling administrative decrees have remained on the books. In the second half of 2014 as the economic crisis intensified the government dusted them off and reintroduced them, along with new taxes on stock market gains, on individual's and company's earnings abroad, and-on a temporary basis - a tax on annual incomes in excess of EGP 1 million. These new taxes, combined with reductions in subsidies, appeared to be intended primarily to send a message to Egypt's present and future creditors that the government was intent on reducing the fiscal imbalance, which by the end of the year was still hovering at around 12 per cent of GDP, thus imperilling Egypt's credit rating and further complicating its desperate need to raise new loans, signalled to be a new issue of a EUR 1 billion bond following the March 2015 donors' conference. The issue of whether the government was intent on real, permanent fiscal reform, or was just seeking to appease its creditors due to its present, desperate need, remained unanswered in 2015, for the promised raises in value added, real estate, and capital gains taxes were postponed yet again in the budget announced in July of that year.

In sum, Egypt's daunting fiscal problems cannot be resolved at a technocratic level. They are too deep and pressing and involve such sensitive political questions of who gets what, when and how that their effective resolution requires direct engagement by the political elite. Since President al-Sisi now towers over that elite, he will have to become personally involved in this decision-making process and identify himself publicly with policy choices if real progress is to be made. Whether he can come to understand the technical complexities and political trade-offs involved, choose decisively and well from among the options, and then sell the policies to those whom they impact will be a primary and presumably early test of his leadership. By the autumn of 2015, his prevarication, vacillation, and cancellation of policy reforms, combined with a fixation on grandiose projects, suggested that he was seeking to 
substitute the latter for the former, a strategy with limited long-term prospects for political or economic success. ${ }^{11}$

\section{$4 \quad$ A New Business Elite?}

Under Mubarak the business community consisted of a private sector dominated by cronies connected to the regime, independent civilian owners of large and medium-sized modernised enterprises, retired officers now running their own firms, a small but emerging 'Islamic' sector composed primarily of leaders of the Muslim Brotherhood, and literally millions of proprietors of micro, small, and traditional, medium-sized companies. That community also included a public sector in which the officer-managers of military companies were steadily growing in importance at the expense of the 'state bourgeoisie' of civilian managers of state-owned enterprises who had played much more important roles in Nasser's and even Sadat's era. ${ }^{12}$ The Mubarak private sector has been accurately characterised as having had a 'missing middle'. Business activity, in other words, was clustered in a few large firms and a multitude of very small ones, the latter of which could not easily expand because of lack of access to capital and a discriminatory regulatory environment. The principal tensions within the business community were at its elite levels, most notably between the cronies connected to the Mubaraks and the generals, active and retired, who managed military enterprises or owned their own companies that existed primarily as contractors to the state, especially the Ministry of Defence, and agencies—such as the Suez Canal Authority—dominated by it. The de facto CEO of this sprawling 'Military Inc'. was Minister of Defence Muhammad Husayn Tantawi, of whom General al-Sisi was a favoured client. In the wake of Mubarak's overthrow, Tantawi, al-Sisi and their fellow officers, acting in concert with anti-Mubarak forces, were able first to bring the cronies to heel; then, after ousting the Brothers in July 2013, they dispossessed the Islamist capitalists. ${ }^{13}$ Paradoxically, the July 2013 coup was made possible in part by support

11 For discussion and analysis of al-Sisi's policymaking style and fixation on grandiose, illthought-out projects, including those for the Suez Canal, land reclamation, housing construction and the building of a new capital, see Springborg (2015).

12 On the shifting balance between the civilian and the military public sectors, see AbulMagd, (2016, forthcoming).

13 The government steadily extended its appropriations of the assets of those it accused of being connected to the Brotherhood. In 2015 it seized the travel agency of Egypt's most famous soccer player, Abu Treika, and the shares Safwat Thabet held in the sprawling dairy conglomerate Juhayna - a company that he had founded and directed. 
from the cronies, who feared the Brothers more than they resented the officers, and so unleashed their media outlets against the former and opened their pockets to the latter. Fully in control, the military then began to selectively rehabilitate once disgraced cronies, including even the notorious Hussein Salem, architect and primary beneficiary of the costly gas deal with Israel (Zaazaa, 2014c). Presumably they were brought into the new, military-dominated fold because of the need for their capital and expertise. Other cronies who rejected overtures from the military, such as Rashid Muhammad Rashid, remained in exile, typically being subject to carrot and stick strategies intended to extract financial commitments to the government from them. New fraud charges were brought against Rashid, while those of tax evasion against Nassif Sawiris were dropped in return for his 'donation' of EGP 2.5 billion to the military's 'Long Live Egypt Fund', which was followed less than a week later by the announcement that the government had approved Sawiris' proposal to build a USD 2-3 billion coal-fired power plant on the Red Sea. One of the Mansour brothers was allowed to return to Egypt to sort out the mess surrounding his joint venture real estate development with a major Emirati firm, presumably as a result of the government's attentiveness to the Emiratis. The other brother, however, remained in his London exile, uncertain of his treatment should he return to Egypt. ${ }^{14}$ During this turmoil, as a new business elite was being configured by the military, independent businessmen who operated medium-sized firms were left to their own devices to cope with political disorder, macroeconomic decay and infrastructural breakdown, including disruption to electricity supplies. ${ }^{15}$ As for the business minnows in small and micro firms, a host of supply and demand problems, including interruptions to the flow of raw materials due to hard currency shortages, rendered their existence yet more precarious.

The new business elite is thus a work in progress under military tutelage. Mubarak cronies, presumably to be joined by others, are scrambling for whatever patronage officers dole out, enhancing their appeal by bringing more retired officers into their companies and forging joint ventures with officer-owned companies. ${ }^{16}$ This fusion notably excludes most of the old state bourgeoisie based in the civilian public sector, a component of the economy treated with contempt by officers, with the notable exception of Arab Contractors, the

\footnotetext{
14 Both brothers have been listed by Forbes as being among the ten richest Africans.

15 For a review of how policy inconsistency has negatively impacted Egypt's once proud textile industry, see Esterman (2015).

16 For examples of these new 'partnerships', see Abul-Magd (2016, forthcoming).

Businessmen in Arms: How the Military and Other Armed Groups Profit in the MENA Region by Elke Grawert (Author), Zeinab Abul-Magd (Author).
} 
former CEO of which-Ibrahim Mahlab, who had long-standing ties with both the presidency and the military-was chosen by President al-Sisi to serve as his first prime minister.

The tightly structured decision-making elite emerging under President al-Sisi will reinforce the importance of access to him and his confidants, simultaneously narrowing it; processes that will impact both the polity and the economy. In the cabinet reshuffle following his election as president, for example, al-Sisi ejected Foreign Minister Nabil Fahmy, who-like Finance Minister Ahmad Galal, who had been dumped in the previous reshufflehad been too high profile and independently minded to be trusted by al-Sisi. Fahmy's successor, Sameh Shukri, had been Mubarak's long-serving head of information within the presidency, and thus someone closely connected to the military, the primary source of staffing for that department. By contrast, Fahmy was a known opponent, when ambassador in Washington, of the further expansion of military influence in the Ministry of Foreign Affairs. Several members of the first al-Sisi cabinet were also members of the board of the Arab Organization for Industrialization, the most important of the three holding companies through which the Ministry of Defence manages Military Inc. The al-Sisi presidency, in other words, is configuring a political-economic elite that depends on the military and those either with well-established ties to it or willing to assist it with their resources in return for a share of the action. Excluded from playing any active role in this emerging political-economic elite and presumably from having their concerns and desires taken into consideration, are virtually all other elements of the business community, including the few occupying the 'missing middle', the remainder of the public sector managerial elite, and the small and micro enterprise owners - this final category paradoxically being the one from which President al-Sisi himself hails. While he might have some lingering sympathies for and interests in this last, struggling component of the business community, its needs could only be met by a thorough overhaul of the bureaucracy and the financial sector, tasks that the new president is unlikely to undertake or achieve.

In sum, the emerging al-Sisi business elite will be more homogenous, smaller and more military dominated than that of his predecessor. Islamist businessmen and public sector officials will be denied significant economic roles, while the design and operation of the economy will be in the hands of the military, assisted by a limited number of recycled cronies with a few new ones likely joining the elite in the future. The independent, medium-sized businessmen who struggle in the missing middle will find their struggle harder still, as will owners of small and micro enterprises. These businesses do not appeal to officers, whose preferred model for the economy is that of major projects 
designed by themselves and implemented by military or crony managers/ owners, frequently in joint ventures with Egyptian or foreign enterprises. They have contempt for the public sector and civilian government more generally, so they will privatise whatever state-owned enterprises they can while creating their own authority structures parallel to the civil administration. Independent businesses of any size, in any sector, will find it increasingly difficult to compete in an economy of this nature. The political elite will be similarly tightly and narrowly structured, thus denying most independent owners of capital avenues of participation, influence, or protest.

\subsection{Labour Force in Search ofJobs}

Even during the period of rapid economic growth from 2002 to 2008, when the official unemployment rate fell to a low-in the final year of the period-of 8.8 per cent, the labour market continued to manifest weakness. The proportion of informal employment provided by small and micro enterprises continued to grow, accounting for more than two-thirds of new entrants into the job market as formal public and private sector employment stagnated. Female participation in the labour market receded in tandem with the relative decline in size of the civil service, as the majority of women in formal employment are employed by the government. The youth unemployment rate continued to be at least double the overall rate. The correlation between education and unemployment intensified as the private sector was generating an insufficient number of skilled jobs, while the public sector was no longer expanding in pace with the growing supply of graduates. Official unemployment figures did not accurately reflect steadily growing underemployment, in part because the definition of employed was anyone working one hour a week or more. Increasingly, the unemployment rate reported primarily the proportion of university and higher technical school graduates who had failed to find jobs, as the less educated simply dropped off the books. Labour market weakness by the end of the Mubarak era could not be attributed in the main to the youth bulge, since by 2012 its peak lay in the $25^{-29}$ age range, and thus above the average age of entry into the job market. In 2006 the peak had been in the market-entering, 15-24 age group (Krafft and Assaad, 2014, 2).

Since the January 25 Revolution the labour market has further deteriorated. Based on the 2012 Egyptian labour market survey and other data, Ragui Assaad and Caroline Krafft conclude that even though demographic pressures have decreased, 'Overall, the labor market post-revolution is in a weaker position than in 2006'. (Assaad and Krafft, 2013a, 1). They further note that Egypt only has a temporary respite from these demographic pressures, as the 'echo' effect of the youth bulge, whereby the leading edge of that bulge come of age 
and these individuals, themselves, become parents, is beginning to be felt. The cohort of o-9 year olds is much larger than that of 10-19 year olds. In all, 2.1 million children were born in 2008, whereas 2.6 million were born in 2012. This increase in births between 2010 and 2012 was 'the largest two-year increase since records began' (Rivlin, 2014, 4). In the coming decade 'there will be an unprecedented number of labor market entrants' as Egypt's population is on course to overtake those of Russia and Japan by 2050 (Krafft and Assaad, 2014, 3). A source of further concern is that a primary cause of the rebound in the fertility rate is a declining rate of employment of women of childbearing age. In 1998, 22 per cent of female high school graduates were employed, whereas in 2012 only 17 per cent were. The equivalent percentages for female university graduates were $5^{6}$ per cent dropping to 41 per cent. This deterioration of female employment figures will presumably drive the fertility rate up still higher, thereby further exacerbating the challenge of job creation.

Segmentation of the labour market and its consequences have become more profound since the January 25 Revolution. The increasingly woeful conditions of the informal sector, combined with inadequate job creation in the formal private sector and successive governments' practice of cultivating support from the civil service by increasing its numbers and pay has caused job entrants to focus more and more on government employment (Assaad and Krafft, 2013b). In the 2014/15 budget, the salaries of government employees, which now consume one quarter of that budget, will increase by 13 per cent over the previous year (Esterman, 2014). During the Mubarak era an outspoken Minister of Administrative Reform stated that Egypt's civil service should not provide more than three million posts if it is to be made more efficient; now it employs in excess of 7 million people. While both the military-dominated and the Muslim Brotherhooddominated governments formed between 2011 and 2014 curried favour with civil servants, President al-Sisi's recurring emphasis on hard work and sacrifice and the need for budgetary austerity, combined with his power now having been consolidated, suggests that the civil service will come under substantial economic pressure, as signalled by the announcement of a new civil service law in March, 2015. If this law and other measures do indeed restrict growth in the size and the overall wage bill of the civil service, this will parallel pressure already being applied to employees of state-owned enterprises, a significant percentage of whom have not been awarded promised minimum wage increases. The pressure being applied to these workers, and to those in private sector concerns, has taken a political form in the banning of strikes-a step called for by the Minister of Manpower, the Prime Minister and various other officials. It was incorporated into legislation decreed under President Adly Mansour and has been sporadically implemented beginning in 2014, most notably in Alexandria 
(Charbel, 2014). Strikes in military-owned enterprises are illegal and employees who have sought to organise them have been prosecuted and imprisoned. Shortly after his election President al-Sisi launched a campaign to remove street vendors in urban areas, despite the fact that the activity frequently represents the last hope for those who have failed to find other employment, as exemplified by the case of Muhammad Bouazizi in 2010 in Tunisia.

The labour force, in sum, faces increasingly bleak employment prospects and a government intent on preventing further industrial action while being simultaneously intent on finding ways and means to limit spending on government employment, virtually the only segment of the labour market that has prospered since 2011. The temporary respite of reduced numbers of young job seekers will soon give way to a renewed surge in those numbers. Prospects for migration have dimmed as GCC states move to restrict expatriate labour. Other potential foreign labour markets, including Europe and North America, are yet more difficult to access. A growing percentage of Mediterranean boat people and the human traffickers transporting them are Egyptian nationals, as reflected by the country being placed in July 2015 on the us State Department's watch list for global trafficking in persons (Cairo Post, 2015). Nothing has been done in recent years to improve the low quality of graduates from secondary and tertiary educational institutions. Such an achievement would, in any case, take years to have an impact on labour markets. In the absence of a dramatic turnaround of the Egyptian economy causing the supply of private sector jobs to surge, the prospects for Egypt's youth, who constitute the lion's share of the unemployed, will continue to deteriorate. The very best that many will be able to envision is a job in Military Inc.; but that segment of the economy, while more robust than others, is unlikely to grow fast enough to make a qualitative difference. In any case the majority of its workers are conscripts, drawn from an overflowing pool in excess of 300,000 men.

\subsection{Key Sectors and Their Maladies}

The two main sectors driving economic growth in Egypt in the first decade of the twenty-first century were tourism and energy/energy-intensive industries. The former's contribution to GDP came to account for about 12 per cent, with a slightly higher contribution to the share of employment resulting from the some 3 million jobs generated by the industry, which rendered Egypt's labour market the world's thirteenth most dependent upon tourism (World Tourism and Travel Council, 2014). The second sector, in the form of gas, steel, cement, ceramics, fertiliser and petrochemicals, came to dominate Egypt's exports of goods and, along with real estate and tourism, the country's ability to attract FDI. The January 25 Revolution has been devastating for both sectors. The 
prospects for their return to the status quo ante, to say nothing of potential expansion, are not encouraging. Tourism, already down from 2010 totals, fell by two-thirds in 2013 from the preceding year, posting its lowest number of visitors in a decade. The comparative magnitude of this impact is illustrated by the fact that, in 2014, of 184 countries ranked according to the contribution tourism made to gross domestic product (GDP), Egypt was placed 35th, while its ranking with regard to prospects for growth in 2014 was 174th (World Tourism and Travel Council, 2014). Gas exports dried up shortly after the January 25 Revolution as the growth of domestic consumption overtook production. By 2014, accumulated payment arrears to foreign companies that had developed Egypt's gas resources and that are owed shares of its production reached some USD 6 billion before a payment of USD 1.5 billion was made by the government prior to the March 2015 donors' conference in the hopes that new exploration and development contracts would then be signed and so address the growing gas shortage. ${ }^{17}$ Cement production fell by 30 per cent in 2013/14 as energy prices escalated. Stopgap measures allowing energy-intensive industries to import their own gas and to construct coal-fired power stations were approved, but the attractiveness of Egypt as a producer necessarily declined as energy costs escalated.

Neither sector will recover quickly. Tourism depends heavily on security and the broader political environment, a fact of which jihadis intent on destabilising the government are well aware. Attacks on tourists in Luxor and the Sinai in 2015, combined with the beheading of a kidnapped Croatian employee of a French energy company that year, reflected this intent. The United Kingdom's declaration in August of that year of most of the Sinai and Western Desert as unsafe for tourism suggested that the prospects for a renewal of the tourist industry had further receded. Egypt's decline on the Global Peace Index in 2014 was the second largest among all countries ranked (Institute for Economics and Peace, 2014). Even if the security and political environments in Egypt were somehow to improve, growing instability in the region, including in neighbouring Libya, would still deter tourists. Egyptian and Western educational, cultural and other institutions based in Cairo or elsewhere in the country, including for example the American University in Cairo, have suffered sharp drops in foreign enrolments, with students, archaeologists and others

17 In 2015 contracts were signed with several international oil companies, which presumably were enticed by dramatic increases in the price offered for the gas that Egypt would buy from them-on average some USD $4.5^{\circ}$ per million втU, more than double the amount under existing contracts. Since this came at a time of declining global gas prices, it suggested Egypt's relative desperation to obtain new supplies. 
establishing new institutional relationships elsewhere, such as in Morocco, considered a safer Arab location. Stagnating remittances coupled with tourism's continuing underperformance will dramatically reduce the heretofore vital contribution of services and invisibles to the balances of trade and payments. In the final decade of the Mubarak era annual tourism receipts alone averaged some USD 10 billion, typically offsetting the annual trade deficit in goods. Inadequate reserves of foreign exchange resulting from the decline of remittances and tourism will in turn impact on other productive sectors, most notably that of manufacturing, which depends heavily on the importation of capital goods and raw materials - one of the reasons this sector has declined at a steadily growing pace since 2011, as evidenced by the performance of manufacturing in general and the textile industry in particular.

The energy/energy-intensive processing sector is equally, if not more threatened by the drastic deterioration of the environment in which it operates. Egypt failed to continue development of its hydrocarbon reserves at a rate sufficient to keep pace with expanding local consumption. It then violated production sharing agreements with BG, ENI, B P and other international energy companies by diverting gas intended for exports to domestic consumption. At least two of these companies commenced proceedings against Egypt for contract violations. Given the present availability of hydrocarbon reserves in many other markets now awaiting development, most notably in the Americas, Egypt's attractiveness is substantially lower than it was in the Mubarak era. ${ }^{18}$ To restore confidence and attract FDI, Egypt has had to pay some of the arrears and commit to paying the balance, while also offering much more favourable contract terms, virtually overnight more than doubling its energy costs as global prices are declining. In the meantime steadily more energy is required to generate electricity for domestic consumption, a decreasing share of which can be allocated to industry. The future of these energy-intensive industries, which will have to rely ever more heavily on imported energy - whether in the form of natural gas, coal, oil or even electricity, which will be at or near global prices-is bleak, for they were all built on the basis of subsidised energy inputs. None require significant labour forces, so Egypt's potential advantage of cheap labour is minimal. All that remains of comparative advantage is location, especially sitting astride the Suez Canal, so that necessarily will become ever more vital to the country's development strategy. Again, however, that is a long-term prospect, payback from which will require many years to

18 On the impact of the contemporary 'energy revolution' on the Arab world and Egypt, see Springborg (2014). 
materialise, thus raising the question of opportunity cost. ${ }^{19}$ The key question then is what happens in the intervening years? How is the government going to structure the economy to meet these pressing challenges?

\section{$5 \quad$ Sisinomics: A Model to Meet these Challenges?}

This brief review of Egypt's fiscal situation and the state of its labour market and key economic sectors suggests that in all three areas the country is in deep crisis. The magnitude and entrenched nature of the problems in each area are such that they are not susceptible to quick fixes. The new regime, however, desperately needs to augment its questionable legitimacy as soon as possible, lest it face renewed challenges from excluded social and political forces, of which there are several, to say nothing of discontented military and security forces. ${ }^{20}$ While it is seeking to substitute ephemeral appeals to nationalism for substantive economic accomplishments, that strategy can buy only limited time. Real personal income - which stagnated even during the boom years of the Mubarak era and which has steadily declined since, with the rate of impoverishment dramatically rising since the January 25 Revolution-requires, for its improvement, both a rapid increase in national income and steps to ensure its more equal distribution. ${ }^{21}$ Given the rate of population growth, annual increases in GDP now would have to be well in excess of 7 per cent to have any real impact on average incomes, a rate which was achieved only briefly

19 For estimates of the years required to reap financial benefits from the USD 8.5 billion invested in the canal upgrade in 2014-15, see Springborg (2015).

2o Reports of attempted coups and protests by security personnel have steadily increased since the military seized power. In August 2015, for example, hundreds of police demonstrated in Sharqiya against the Ministry of Interior, which responded by alleging their ranks had been infiltrated by members of the Muslim Brotherhood, an allegation also made in response to previous police strikes in Alexandria and Kafr al Shaykh in February 2014 (Ahram Online, 2015a). In May 2015, more than twenty officers suddenly disappeared from their army posts. In August it was reported that they had been tried for, and convicted of, trying to overthrow President al-Sisi, for which they were sentenced to between 10 and 25 years in prison. The group included four colonels (Middle East Eye, 2015). It has long been argued that income inequality in Egypt is not particularly pronounced by comparison to other lower-middle and middle-income countries. Recent research, however, calls that proposition into question, presenting evidence to the effect that in the Middle East generally and Egypt specifically income inequality 'is substantially higher than in the us or Europe [and] at least as large as in the most unequal emerging or developing regions (e.g. in Latin America or South Africa)'. (Alvaredo and Piketty, 2014, 2). 
during the gas-fired boom years of the Mubarak era. GDP growth in 2014-15 was less than 3 per cent and IMF forecasts for growth in the next few years do not exceed 5 per cent. Since no windfalls are likely, whether in the form of privatisations of state-owned enterprises, confiscation of foreign assets, or a surge of hydrocarbon exports, and since broad economic growth across several sectors would require a thorough overhaul of both state and market, almost any new leadership would find the task of stimulating sustained growth a difficult one.

In the event, Egypt's new leadership is ill-equipped to forge and then implement a successful model for economic growth. Its core of military officers is made up at best of competent managers of companies, at worst of corrupt, rent seeking comrades with a strong sense of entitlement to their privileges. None have substantial experience of broader economic analysis, nor of economic policy formation. The rapid turnover of civilian specialists brought in by the military since 2011 to oversee economic policy suggests that meshing their expertise and recommendations with the preferences and ideas of their officer bosses is not easy. The 'first string' of economists was sidelined, and a second string was then fielded by the al-Sisi government. The present Minister of Finance has a degree in accounting, not economics. Many of these newly recruited experts have neither the professional reputations nor the independent bases of power of their predecessors, suggesting that the officer bosses do not want to hear independent advice, especially from those who might claim to represent constituencies. As for the business sector, the return of cronies indicates that a marriage between them and Military Inc. is being arranged, much to the detriment of other businesses and to the labour force as a whole.

The magnitude and immediacy of the economic challenges faced, combined with the limitations of the al-Sisi government, suggest what the likely strategy and the process of its formulation will not be. Not being an inclusive, representative government, the al-Sisi regime is not going to seek consensus on economic policy. Instead, it will operate more as a military command, with a small group of senior figures who conceive and direct policy. The delivery of goods and services will be conceptualised in a fashion analogous to a military campaign, with top-down orders to field units, many of the key elements of which will be from Military Inc. The notion that the economic forces of civil society can better provide goods and services so long as they operate within conducive governance structures is alien to the military officers in control and even to the cronies at their sides, whose wealth was accumulated through rents, not through market competitiveness. Poverty will be addressed to an extent, but through the delivery of rationed goods and services, many of which are already produced by the military, not through a coherent, unified plan for broadbased, job creating, economic growth. Alongside the 'welfare' component 
of the economy will be economic activities at which the officers and cronies excel. Most if not all of these depend upon strategic relations with the state, the most important of which include the provision of goods and services to the state, infrastructural development, and other essentially land based activities such as housing construction, as well as agency agreements with international companies seeking access to local markets or relatively small export platforms primarily servicing regional markets. Some of these undertakings will take on the character of national prestige projects, similar to those of President alSisi's predecessors, including Nasser's Mudiriyya Tahrir (Liberation Province) or Mubarak's Tushka, both ill-fated, large-scale reclamation projects. The example of a much-publicised joint venture between the military and an Emirati real estate company to construct low-cost housing is a case in point in the welfare sector. In the productive economy the main project will be the development of the Suez Canal Zone and surrounding area-the land and maritime access to it being controlled by the military, either directly or indirectly through the Suez Canal Authority and its subsidiary holding companies. The government clearly hopes that this strategic location will provide not just an economic, but a geopolitical inducement for potential investors, presumably including Chinese, Russians and others wanting to sit astride the canal for both political and economic reasons.

Indeed, the mix of economic and political motives is the key to understanding how the al-Sisi government will try to restructure the economy. Just as the geopolitical attractiveness of the Suez Canal may generate rents, so can other of the country's assets, a key example of which is political-military power. Subventions from the GCC states-most of which have gone directly to the military as general budgetary support, for specific projects such as the real estate development just mentioned, or in the form of supplies of oil or gas-are intended by the donors to harness Egypt's hard and soft power for various struggles, whether against Iran, Syria, Turkey, Qatar, Libya or elements of their own populations, key examples of which are the Muslim Brothers and their fellow travellers. ${ }^{22}$ This manna from heaven provided to the very core of the Egyptian military-dominated political-economic elite will have the usual distorting effect of rents, as that elite shapes the economy by the very act of pursuing those rents. The Gulf economies are themselves lopsided and rent seeking, struggling to cope with the progressive decline of the rent/population ratio, a decline that accelerated following the collapse of oil and gas prices in the second half of 2014. But even if they were veritable paragons of development virtue, their motive is not Egypt's economic well-being, but rather its political 
and military support. Keeping Egypt on an economic lifeline that enables the incumbent regime to hold its head above water is, in fact, a better outcome for GCC patrons than an economically independent Egypt. So the rent takers and rent providers will have common interests, but these interests will not prioritise the country's economic development over benefiting those responsible for it. More or less the same can be said of Western support for Egypt, which is increasingly motivated by security concerns rather than by development needs or sheer profit motives. FDI is even more concentrated in the energy sector under the al-Sisi government than it was previously, in part because tourism has lost its investment lure. Integration into global production chains resulting from multinational corporate investment has become an even more distant hope than it was prior to 2011 .

Moreover, a fundamental contradiction exists between Egypt's rent seeking and its economic development. The former, reinforced by the regime's need for domestic legitimacy, drives it to accentuate the issues of terrorism, political violence and regional unrest, driven by Islamist fanatics or Shi'a agents of Iran, emphasising Egypt's role as a bulwark against these evils, including-most importantly-domestic ones. The primary message then is that Egypt is at the very epicentre of an existential struggle against terrorism, a message reinforced by the words and deeds of both the Obama Administration and the European Union. This message, however, is not one that reassures potential global or even regional investors in the Egyptian economy. If Egypt is to be integrated into global production chains that would gainfully employ its people, then it needs to be perceived by multinational corporations, even those based in China, as a stable country at peace with itself and its neighbours. This manifestly is not the case, but it should be the government's stated and actual objective if it wants to develop the economy in a meaningful, sustainable way. Instead, however, President al-Sisi is crying wolf out of his need for rents from external patrons and loyalty from his own, fearful citizens, thereby scaring off many potential investors.

The al-Sisi-inspired ideological project of a tough, austere state inspired by the moral virtues of Islam will further accentuate the perception of Egypt as a risky place to invest. ${ }^{23}$ One of his first acts upon assuming power- to have the cabinet form a committee to 'fight atheism' - underscored, for observers already concerned about violations of human and civil rights, including those of international journalists, that this is a government hunkering down against many opponents, real and imagined, while emphasising its distinctively

23 For an assessment of the political uses of Islam by the al-Sisi government, see Hearst (2015). 
religious character (Saber, 2014). As Noland and Pack have observed, perceptions of this sort are deleterious in numerous ways for a country's development prospects, discouraging - for example — its very own globalised expatriates from committing their skills and capital to their de-globalising homeland (Noland and Pack, 2011, 251-260). An emphasis on struggle, conflict and an austere, religiously inspired morality, with the military and security services playing the key role in combatting evil and doing good, is a message with resonance in Saudi Arabia and possibly Moscow, but not in London, Berlin, Paris, Tokyo, New York or probably even Beijing, or with most Egyptian skilled expatriates. Multinational corporations have already expressed concerns about reputational costs associated with doing business in Egypt with the military and military-owned companies. ${ }^{24}$

\section{Conclusion}

Al-Sisi's Egypt is doubling down on what preceding regimes in that country and those elsewhere in the world have demonstrated to be a failed strategy for economic development. That strategy is formulated and implemented by a military pursuing mixed and contradictory aims of national economic growth, enrichment and empowerment of itself and its officers, and enhanced coercive powers, both domestic and regionally. Inevitably these regimes emphasise nationalism, conflict and struggle and the central role of those in charge in combatting these threats. Economic development is conceptualised as the task of those in charge, who arrogate to themselves the country's resources in vain attempts to accelerate growth. Civil society and even civilian government are viewed by the officers in charge with suspicion, even contempt, and so are not called upon to, and hence do not, contribute effectively to economic development.

It is, therefore, only a matter of time before yet more profound economic failure, possibly combined with military adventurism, undermines this regime. In the meantime and even thereafter, the Egyptian economy is unlikely to return even to the level of growth achieved under Mubarak, which was inadequate for a smaller population. The key question is thus not how to develop Egypt, but how to save it from becoming a basket case similar to Yemen or Sudan. Sisinomics will not provide the answer.

24 The author has been made aware of these concerns through consulting work with various multinational companies presently working in, or interested in working in, Egypt. 


\section{References}

Abaza, D. (2014a) 'Suez Cement Sees Profits Drop, as Chairman Blames Energy Shortage', Ahram Online, 30 October, http://english.ahram.org.eg/News/114349.aspx (accessed 8 May 2016).

Abaza, D. (2014b) 'Egypt Ranks 112th in World Bank's Annual Doing Business Report', Ahram Online, 29 October. http://english.ahram.org.eg/News/114251.aspx (accessed 8 May 2016).

Abul-Magd, Z. (2016, forthcoming) Militarizing the Nation: Army, Business, and Revolution in Egypt (New York: Columbia University Press).

Ahram Online (2015a) 'Brotherhood behind low ranking policemen strike: Security source' August 22, http://english.ahram.org.eg/News/138537.aspx (accessed 8 May 2016).

Ahram Online (2015b) 'Egypt's Ezz Steel Says Output Hit by Forex Shortage' August 20, http://english.ahram.org.eg/News/138344.aspx (accessed 8 May 2016).

Ali, R. and W. Ahmed (2015) 'Doubts Hover over Egypt's Civil Service Law', Ahram Online, August 19, http://english.ahram.org.eg/News/138162.aspx (accessed 8 May 2016).

Alvaredo, F. and T. Piketty (2014) 'Measuring Top Incomes and Inequality in the Middle East: Data Limitations and Illustration with the Case of Egypt', Working Paper No. 832 (Giza: Economic Research Forum), http://erf.org.eg/wp-content/ uploads/2014/07/832.pdf (accessed 9 May 2016).

Assaad, R. and C. Krafft (2013a) 'The Evolution of Labor Supply and Unemployment in the Egyptian Economy: 1988-2012', Working Paper No. 806 (Giza: Economic Research Forum), http://erf.org.eg/wp-content/uploads/2014/02/806.pdf (accessed 9 May 2016).

Assaad, R. and C. Krafft (2013b) 'The Structure and Evolution of Employment in Egypt: 1998-2012', Working Paper No. 805 (Giza: Economic Research Forum), http://erf.org .eg/wp-content/uploads/2014/07/805.pdf (accessed 9 May 2016).

Assaad, R., E. Badawy and C. Krafft (2014) 'Differences in Pedagogy, Accountability, and Perceptions of Quality by Type of Higher Education in Egypt and Jordan' Working Paper No. 828 (Giza: Economic Research Forum), http://erf.org.eg/wp-content/ uploads/2014/07/828.pdf (accessed 9 May 2016).

Cairo Post (2015) 'Egypt Downgraded to "Watch List" in Fighting Human Trafficking: U.S. Report' July 28, http://www.thecairopost.com/news/161552/news/egypt-down graded-to-watch-list-in-fighting-human-trafficking-u-s-report (accessed 8 May 2016).

Charbel, J. (2014) 'Govt Moves to Outlaw Strikes, but is it Promoting Production?' mada masr, June 17, http://www.madamasr.com/content/govt-moves-outlaw-strikes-it -promoting-production (accessed 8 May 2016). 
Chekir, H. and I. Diwan (2013) 'Distressed Whales on the Nile-Egyptian Capitalists in the Wake of the 2010 Revolution', Working Paper 747, (Giza: Economic Research Forum), http://erf.org.eg/wp-content/uploads/2014/03/747.pdf (accessed 9 May 2016).

El-Haddad, A. (2013) 'Political Patronage and Economic Opportunity: The Case of Vertical Integration in the Egyptian Clothing Industry', Working Paper 756, (Giza: Economic Research Forum).

Esterman, I. (2014) 'Sisi Meets Egypt's Economic Hurdles' mada masr, June 3, http:// www.madamasr.com/content/sisi-meets-egypts-economic-hurdles (accessed 8 May 2016).

Esterman, I. (2015) 'Inconsistent Policy Changes are Putting Egypt's Cotton Industry in Crisis' Mada Masr, August 19, http://www.madamasr.com/sections/economy/ inconsistent-policy-changes-are-putting-egypt\%E2\%80\%99s-cotton-industry -crisis (accessed 8 May 2016).

Hearst, D. (2015) 'The Fatwa of “Ayatollah" al-Sisi' Middle East Eye, August 18, http:// www.middleeasteye.net/columns/fatwa-ayatollah-al-sisi-1867588370 (accessed 8 May 2016).

Institute for Economics and Peace (2014) Global Peace Index (Sydney: IEP), http:// reliefweb.int/sites/reliefweb.int/files/resources/2014\%2oGlobal\%2oPeace\%2o Index\%2oREPORT.pdf (accessed 8 May 2016).

Krafft, C. and R. Assaad (2014) 'Beware of the Echo: The Impending Return of Demographic Pressures in Egypt' Policy Perspective, 12 (Giza: Economic Research Forum).

Mayfield, J.B. (2012) (2012), Field of Reeds, Social, Economic and Political Change in Rural Egypt: In Search of Civil Society and Good Governance (Bloomington: AuthorHouse).

Middle East Eye (2015) cited in Marsad Egypt, '26 Egyptian Officers Allegedly Jailed for Plotting Coup against Sisi', August 17, http://www.marsad.eg/en/26-egyptian -officers-allegedly-jailed-for-plotting-coup-against-sisi/ (accessed 8 May 2016).

Morsy, A. (2014) 'The Military Crowds out Civilian Business in Egypt', (Washington, DC: Carnegie Endowment), http://carnegieendowment.org/2014/o6/24/military -crowds-out-civilian-business-in-egypt/hedq (accessed 8 May 2016).

Noland, M. and H. Pack (2011) The Arab Economies in a Changing World. (Washington DC: Peterson Institute for International Economics), 2nd ed., $362 \mathrm{p}$.

Rivlin, P. (2014) 'Sisi as Sisyphus: Egypt's Economic Emergency', Middle East Economy (Tel Aviv University), Vol. 4. No. 6, June 19, http://dayan.org/content/iqtisadi-sisi -sisyphus-egypts-economic-emergency (accessed 8 May 2016).

Saber, A. (2014) 'Govt Announces Campaign to Save Youth from Atheism' mada masr, June19,http://www.madamasr.com/content/govt-announces-campaign-save-youth -atheism (accessed 8 May 2016). 
Sekkat, K. (2014) 'Is there Anything Special with Intra-Arab Capital Flows', Working Paper 812, (Giza: Economic Research Forum).

Shikaki, K. et al. (2011) The State of Reform in the Arab World: The Arab Democracy Index, Arab Reform Initiative/Palestinian Center for Policy and Survey Research, http://www.arab-reform.net/sites/default/files/Full\%2oReport_o.pdf (accessed 8 May 2016).

Springborg, R. (2012) 'Gas and Oil in Egypt's Development' in Robert E. Looney, ed., Handbook of Oil Politics (London: Routledge) pp. 295-311.

Springborg, R. (2013) 'Governance in Egypt', in Abbas Kadhim, ed., Governance in the Middle East and North Africa (London and New York: Routledge), pp. 399-416.

Springborg, R. (2014) 'The Energy Revolution's Impacts on the Arab World', Policy Focus Series (Washington, DC: Middle East Institute), http://www.mei.edu/ content/article/energy-revolution\%E2\%80\%99s-impacts-arab-world (accessed 8 May 2016).

Springborg, R. (2015) 'President Sisi's Delegative Authoritarianism', Working Paper 15 (Rome: Istituto Affari Internazionale), http://www.iai.it/en/node/4450 (accessed 8 May 2016).

Springborg, R. (2016, forthcoming) 'Egypt: The Challenge of Squaring the EnergyEnvironment-Growth Triangle', in Robert E. Looney, ed., The Routledge Handbook of Transitions to Energy and Climate Security (London and New York: Routledge).

World Bank (2016) Gross savings (\% of GDP), World Development Indicators, http:// data.worldbank.org/indicator/NY.GNS.ICTR.ZS (accessed on 22 April 2016).

World Tourism and Travel Council (2014) Travel and Tourism: Economic Impact 2014, Egypt, (London: WTTC).

Zaazaa Sherif, S. (2014a) 'Tax Talks' mada masr, April 22, http://www.madamasr.com/ content/economy-week-tax-talks (accessed 8 May 2016).

Zaazaa Sherif, S. (2014b) 'Egypt Reclassified as Frontier Market', mada masr, March 10, http://www.madamasr.com/sections/economy/economy-week-egypt-reclassified -frontier-market (accessed 8 May 2016).

Zaazaa Sherif, S. (2014c) 'Egypt Welcomes Back Mubarak-era Cronies' mada masr, February 9, http://www.madamasr.com/content/economy-week-egypt-welcomes -back-mubarak-era-cronies (accessed 8 May 2016). 